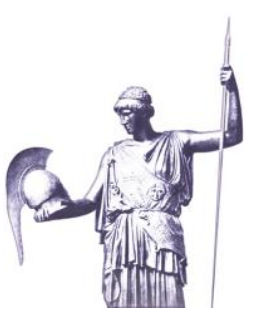

Research Article
Connections: The Quarterly Journal

ISSN 1812-1098, e-ISSN 1812-2973

Nasirov, Iskandarov, and Sadiyev, Connections QJ 16, no. 3 (2017): 47-56 https://doi.org/10.11610/Connections.16.3.03

\title{
The South Caucasus: A Playground Between NATO and Russia?
}

\section{Elman Nasirov, ${ }^{a}$ Khayal Iskandarov ${ }^{b}$ and Sadi Sadiyev ${ }^{b}$}

a Institute of Political Studies of the Academy of Public Administration under the President of Azerbaijan

b War College of Armed Forces, Republic of Azerbaijan

\begin{abstract}
In this article, the challenges and prospects of cooperation between the South Caucasus countries and NATO have been analyzed. The geo-economic, geopolitical and geostrategic importance of the region for both NATO and the Collective Security Treaty Organization (Russia particularly) and reciprocal expectations of further cooperation with the Alliance have been considered. The regional state of affairs in the South Caucasus has been analyzed and the possible impacts of Russian influence on forging closer relations with NATO have been examined. The security environment after the Russo-Georgian war and its repercussions for the South CaucasusNATO cooperation have been illustrated. NATO's vested interest in the region to contribute to a European security system for the foreseeable future was brought to the fore. The reasons for the Alliance's reluctance to actively engage in the region are examined. The recommendations are intended to counterbalance the Russian military presence in the region, without antagonizing the incumbent government in Moscow, and to eradicate the so-called "frozen conflicts" in order to maintain security and prosperity for the South Caucasus region as a whole.
\end{abstract}

Keywords: NATO, security, contribution, cooperation, frozen conflict, membership, counterbalance. 


\section{Introduction}

In terms of its geopolitical and strategic importance, the South Caucasus has always been at the forefront of the foreign policy of global powers. While the region was once considered to be on the periphery of the international agenda, after the dissolution of the Soviet Union and the subsequent formation of newly independent states, it became much more important both to its neighbors and to influential non-regional actors. ${ }^{1}$ Today the South Caucasus is a diverse geopolitical region, which occupies a strategic position in the transportation of Caspian oil and gas. However, the region is challenged with unresolved conflicts and socio-political and economic problems brought about by the collapse of the Soviet Union. ${ }^{2}$ The protracted conflicts in the region have long been a source of tension for both Georgia and Azerbaijan. Though NATO does not take a direct part in the resolution of conflicts on the territory of a country outside the Alliance, the crises in the South Caucasus are largely influenced by the relationship between NATO and Russia.

\section{The South Caucasus - A Venue for Contradicting Interests}

After Bulgaria and Romania joined NATO in 2004 and then the European Union in 2007, the South Caucasus began to be considered a new frontier for NATO and the whole structure of European security. ${ }^{3}$ Apart from this, for NATO and its members, the role of the South Caucasus is extremely important in terms of Eurasian security as well. Many European political scientists see the South Caucasus as a center of economic interest and an important transportation corridor. ${ }^{4}$ Other factors have also fueled interest in the region. Foremost among these are its natural resources (the Caspian basin) and the proximity of three major and ambitious Eurasian states: Russia, Turkey and Iran. The region plays a crucial role as a transport and energy corridor. Today Europe relies heavily on Russian oil and natural gas. However, the EU is aiming to prevent Russia from wielding energy as a coercive tool and the Caspian basin has the utmost importance in this policy. ${ }^{5}$ Thus, the Azerbaijan-Georgia-Turkey corridor is a critical strategic link between Europe and Central Asia for challenging Russia's current stranglehold

1 Sergey Markedonov, "NATO Looks to the Caucasus," The National Interest, May 17, 2012, http://nationalinterest.org/ commentary/nato-looks-the-caucasus-6933.

2 Joshua Bartlett and Nino Samvelidze, "Turkey and the South Caucasus: Prospects and Challenges for Cooperation," http://oval.az/turkey-and-the-south-caucasusprospects-and-challenges-for-cooperation/.

3 Markedonov, "NATO Looks to the Caucasus."

4 Tamaz Papuashvili, "Georgia-NATO: Cooperation Prospects," http://gcssi.org/wp2/ $? p=5139$.

5 Eric S. Thompson, "Turkish Influence in the South Caucasus and Levant: The Consequences for NATO and the EU," (Monterey, California: Naval Postgraduate School, September 2013), 37. http://calhoun.nps.edu/bitstream/handle/10945/37733/ 13Sep_Thompson_Eric.pdf. 
on energy resources. This corridor includes the production and transportation of hydrocarbons.

The paths of the three South Caucasus republics have been different in terms of their geo-political orientations, with Armenia being a CSTO member, Azerbaijan pursuing an independent policy regarding global powers, and Georgia, apparently, demonstrating a pro-NATO position. The lack of diplomatic relations between Armenia and Azerbaijan due to the Nagorno-Karabakh conflict, Russia's increased assertiveness in the region and the absence of a NATO presence are central elements in understanding the current situation in the region. What we can gather from this situation is that the South Caucasus is a complex playground between Russia and NATO.

Though NATO has a limited role, Russia is very much engaged in the region, as recent and on-going conflicts illustrate, and has been exercising substantial leverage and influence for a considerable time. After the collapse of the Soviet Union, Russia has been intent on dominating the post-soviet countries and declared this strategy as a priority for its foreign policy. Russia's presence in the region is extensive, including its military participation in Armenia and Georgia's breakaway entities. Nevertheless, the way common interests might be translated into joint opportunities depends not only on Russia's policy towards the South Caucasus, but also on how Russia-NATO relations evolve. That is why the national security interests and foreign policy goals of these states must be part of the bargaining process, despite their position regarding Russia and NATO. ${ }^{6}$

The crucial point in formulating NATO's future engagement in the region is that membership of NATO is not an issue. NATO's broad variety of programs serve to transform the regional security picture overall - with or without membership. The Partnership for Peace (PfP) program is an invaluable tool in building political and military bridges between NATO members and partner nations. ${ }^{7}$ It increases security in the region and contributes to its political, social and economic development. Through its activities, PfP has proved to be a very successful mechanism in promoting and developing defense cooperation and military interoperability between NATO and the South Caucasus countries. But the extent and depth of cooperation with Azerbaijan and Georgia is of a different order than that with Armenia. From 2003, when Mikheil Saakashvilli came to power, Georgia consistently declared that it was pursuing NATO membership until August 2008, when the Russian army invaded its territory. As a corollary to that invasion Georgia has become more prudent in its relations with Russia. A long period of time has elapsed since that invasion, and Georgia is no longer as close to NATO

6 Maria Raquel Freire, "Security in the South Caucasus: the EU, NATO and Russia," NOREF Policy Brief (Norwegian Peacebuilding Resource Centre, February 2013), accessed June 4, 2017, https://noref.no/Publications/Themes/Emerging-powers/ Security-in-the-South-Caucasus-the-EU-NATO-and-Russia.

7 Nika Chitadze, "NATO: One of the Main Guarantees of Peace and Security in South Caucasus," in Perceptions of NATO and the New Strategic Concept, ed. Luis Nuno Rodrigues and Volodymyr Dubovyk (Amsterdam: IOS Press, 2011), 61-73. 
membership as it was before the August war though it still has a strong presence in NATO operations and solid credentials in meeting the Alliance's military and political standards. In fact, Russia has demonstrated its continued presence in the region through its military actions in Georgia. This signal was immediately and accurately read by a careful Azerbaijan, which, thereafter, strengthened the multi-vector nature of its foreign policy amidst the region's geopolitical rivalries and joined the Non-Aligned Movement (NAM) in 2011. ${ }^{8}$ By joining NAM Azerbaijan has declared that it is not seeking membership of either NATO or CSTO at the moment. However, the Republic of Azerbaijan with its growing international prestige attaches great importance to the development of relations with NATO. Today, international authorities highly appreciate the steps taken by Azerbaijan in ensuring regional and global security and safeguarding its interests on reciprocal bases. ${ }^{9}$ Though it has no direct intention to join NATO, Azerbaijan is deemed NATO's most reliable partner in the region. This was recognized by the Assistant Secretary General of NATO Sorin Ducaru speaking at the conference marking the $20^{\text {th }}$ anniversary of program "Partnership for Peace" on April 11, 2014 when he said, "Azerbaijan is one of the most important, active and longterm partners of NATO. We are actively developing a political dialogue with Baku." ${ }^{10}$ As NATO's reliable partner, Azerbaijan's cooperation with the Alliance extends to many areas including the fight against terrorism, regional security, contribution to international security and, in particular, Azerbaijan's support for NATO operations. In this regard, Azerbaijan aspires to achieve NATO military standards and get closer to its military institutions. NATO's political priorities and security interests chime with Azerbaijan's national interests and further improvements in multilateral relations is the main guarantor of peace and security in the region.

The arguments in favor of continuing South Caucasus-NATO relations can be grouped as follows:

- It increases confidence in the security of the South Caucasus region

- It ensures the security of oil and gas production and transportation

- The most important problems in the region-the so called "frozen conflicts" - might be solved by peaceful means

- $\quad$ Armed Forces become interoperable with NATO Forces.

If the South Caucasus-NATO cooperation acts as a guarantor of the region's security, then the nature of all possible threats should be analyzed. So, what

8 Cavid Veliyev, "Can Trump Shake Up the South Caucasus?" The National Interest, December 18, 2016, http://nationalinterest.org/feature/can-trump-shake-the-southcaucasus-18774.

9 Dhmədov T. "Azərbaycan-NATO əlaqələri genişlənir," Respublika qəzeti, Bakı, fevral 26, 2012, № 046, s.1.

10 Khayal Iskandarov, "The Road of Integration of Azerbaijan into NATO (1994-2014)," The Caucasus and the World 19 (2015): 89. 
threats are there in the region? In the current socio-political climate, the obvious threats are most probably from those countries with which NATO's economic and political interests contradict. Thus, in order to understand the nature of these threats, it is necessary to determine the areas of conflicting interests. The first and foremost of these is the Caspian oil and gas fields. In this domain NATO's interests clash seriously with Russian interests and the latter has been using the "frozen conflicts" for decades in order to keep the region and its oil and gas infrastructure of the country under threat. In fact, these conflicts, interspersed with numerous asymmetrical threats in the region, present a challenging environment on NATO's eastern front. Russia is playing a dual game in the South Caucasus at the same time both stabilizing and destabilizing the region. On the one hand, there is Russia the conflict-mediator, the one that brokers ceasefires and seeks to resolve the South Caucasian conflicts via its mandate as co-chair of the Minsk Group of the Organization for Security and Cooperation in Europe. On the other hand, there is Russia the provoker. Having already provoked its own war with Georgia in 2008, Russia recognized two of the Georgia's breakaway regions as independent states and is still militarily present in their territories. ${ }^{11}$ Russia also supports Armenia, which has occupied 20 percent of Azerbaijan's territory, both economically and militarily.

Today Russia accuses NATO of destabilizing the Caucasus region with joint exercises in Georgia, but itself has stationed permanent military bases in Armenia, as well as in the separatist regions of South Ossetia and Abkhazia. Emboldened by Russian support, Armenia still keeps Nagorno-Karabakh under its occupation. However, the West does not have an effective political or military tool to balance Russia's military presence in Armenia. The unbalanced and overwhelming Russian military presence in Armenia creates a serious and direct threat to Western oil and gas infrastructures and pipelines. ${ }^{12}$ Yet, Russia has been using its role as a mediator for advancing its own interests rather than the actual conflict resolution. As long as the three South Caucasus states are divided, Russia can rule them. It is not a secret that South Caucasus conflicts serve Russia as political leverage over Georgia, Armenia and Azerbaijan. In a nutshell, Russia has been applying a divide and rule policy through protracted conflicts. Indeed, the current status quo is clearly beneficial to Russia's interests, preserving an economic and military sphere of influence while preventing any of the South Caucasian states from looking towards NATO.

11 Tatia Dolidze, "Russian and Western engagement in the South Caucasus conflicts: Building sustainable stability in the region?" December 2, 2015.

12 Mahir Khalifazadeh, "The South Caucasus: Obama's Russia 'Reset' and Putin's Doctrine," CESRAN International, July 27, 2014, http://cesran.org/the-south-caucasusobamas-russia-reset-and-putins-doctrine.html. 


\section{NATO's Raison d'être of Further Engagement in the Region}

NATO attaches considerable importance to the Caucasus region and so it is concerned by the escalation of tensions in the area. All three countries are in Europe's Eastern Partnership and the security in its neighborhood is one of NATO's core interests. However, due to a number reasons there has been less effort from NATO to actively contribute to security in the South Caucasus. Indeed, NATO lacks coherence in its policy towards South Caucasus. First and foremost, the Alliance is careful not to anger Russia. The Russian-Georgian war and the Ukraine crisis have made the West more reluctant to intervene and so expansion into the South Caucasus is not expected to be on NATO's agenda in the foreseeable future. However, we can assume that NATO can counterbalance Russia and facilitate the overall integration of the region into NATO institutions through its partnership programs. While talking about the prospects of cooperation between the South Caucasus countries and NATO, various regional factors have to be kept in mind. At the 2008 Bucharest summit, Russian President Vladimir Putin declared that he regarded the existence of a powerful military alliance on its near borders as a direct threat to Russia's national security and national interests. ${ }^{13}$ In addition, he made the following remarks on Georgia and Ukraine:

It [the Georgian conflict] is an old, many-years, lasting for more than a hundred years ethnic conflict between Georgians, ... Abkhazians, ... Ossetians. ... To solve these problems they need not to enter NATO, they should have patience, establish dialog with small ethnic groups. And we have been trying to help them. ... But in Ukraine, one third are ethnic Russians. Out of forty-five million people, in line with the official census, seventeen million are Russians. There are regions, where only the Russian population lives, for instance, in the Crimea $90 \%$ are Russians. ... Well, seventeen million Russians currently live in Ukraine. Who may state that we do not have any interests there? ${ }^{14}$

Consequently, though President Bush strongly supported Ukraine and Georgia becoming NATO MAP (Membership Action Plan) members, the United Kingdom, France and Germany opposed the idea. The British judgment is that, although they fully supported both Ukraine and Georgia, the question of when they joined should remain in the balance. Germany and France said they believed that since neither Ukraine nor Georgia was stable enough to enter the program then,

13 Nəzakət Məmmədova, "NATO: Şimali Atlantikadan Şərqi Avropaya doğru," Xalq qəzeti 81, aprel 18, 2008, s.5.

14 "Text of Putin's speech at NATO Summit," UNIAN (Bucharest, April 2, 2008), http://www.unian.info/world/111033-text-of-putins-speech-at-nato-summitbucharest-april-2-2008.html. 
a membership plan would be an unnecessary offense to Russia. ${ }^{15}$ Germany is still skeptical, fearing that Georgian accession will drag the Atlantic Alliance into a confrontation with Russia. Thus, even if it is temporary, Russia has managed, for the foreseeable future, to prevent any NATO expansion towards the 2008 postsoviet borders because Russian military intervention remains a credible threat to all post-soviet countries in its proximity.

NATO may be the sine qua non for security in the South Caucasus. But, it does not mean that the South Caucasus countries have to be full members. The most promising and perhaps single means of redressing the "security deficit" in the South Caucasus is through the gradual extension of NATO programs into the region. Regional states, including Armenia, are now gradually realizing that their relations with NATO are in fact concerned with how to select, develop, and incorporate NATO programs that will, increasingly over time, transform the overall regional security picture. ${ }^{16}$

Whilst new global risks emerge, the security domain enlarges towards unusual security issues, which require a fast adaptation of traditional institutions, enlarging their responsibilities, tasks and sometimes also the tools at their disposal. Energy security is the main concern among those issues. Nowadays energy has been more politicized, becoming an effective weapon for coercion and creating irreconcilable differences between energy owners and consumers. Since NATO admits that energy security is quickly becoming a growing concern for European security and will be one of the most important future challenges for Allies, the significance of the South Caucasus has increased considerably. As a result of the political friction in the energy relationship between the EU and Russia in spring 2006, and later between Russia and Ukraine in January 2009, member states have called for NATO involvement in energy security. ${ }^{17}$ But, the lack of a consensus among members has not allowed NATO to have a wider involvement in energy security. Other institutions, such as the EU, may have a key role to play and are more suited to resolving the major problems of investment and efficiency. But, NATO could still make a positive contribution to the energy security of its members and indeed more globally. Moreover, a lack of clarity about NATO's role and the reasons behind it, particularly in terms of its geographical role, could complicate NATO's relations with partner countries and other third parties (Russia in this case). The importance of ensuring energy security once again was underscored and endorsed by Allies in November 2010. The $13^{\text {th }}$ paragraph of NATO Strategic Concept recognized the increased dependence of

15 Steven Erlanger and Steven Lee Myers, "NATO Allies Oppose Bush on Georgia and Ukraine," New York Times, April 3, 2008, http://www.nytimes.com/2008/04/03/ world/europe/03nato.html.

16 Chitadze, "NATO: One of the Main Guarantees."

17 Chitadze, "NATO: One of the Main Guarantees." 
states on "vital communication, transport and transit routes on which energy security, international trade and prosperity depends." 18

The main obstacles to a pivotal role for NATO in energy security within the Caspian region are ${ }^{19}$ :

- A lack of means and tools at NATO's disposal, which impedes attempts to implement the intentions expressed in NATO's Strategic Concept

- Russia's reluctance to engage in a joint effort with NATO. Any action that the Alliance would implement, especially involving the military, could give rise to a Russian reaction to counterbalance the Euro-Atlantic presence in such a vital region of its national interest

- Discord within NATO for a greater NATO commitment to energy security

- Weak cooperation on energy security with Caspian partners.

However, the ever-increasing need for the diversification of energy sources and cooperation in energy transit issues has, perhaps, made the West attach a great deal of importance to the South Caucasus region (Azerbaijan-Georgia-Turkey corridor) as a reliable transit route avoiding Russian and Iranian territories. The Baku-Tbilisi-Ceyhan oil pipeline and Baku-Tbilisi-Erzurum natural gas pipeline represent a step forward in this cooperation, especially combined with the upcoming TANAP and TAP projects. ${ }^{20}$ The further development of the Caspian region will have a considerable impact on the strategic balance in the world providing the key to access Central Asian resources. South Caucasus' role in ensuring the energy security of Europe is also welcomed by the U.S. The White House strongly supports the Azerbaijan-initiated Southern Gas Corridor project, which will carry the "Shah Deniz II" gas to European consumers. John Kerry said that "this project was a very important step with respect to Europe's long-term strategic interests and frankly, to try to diversify the sourcing of energy, which is important." ${ }^{21}$ As a result of this policy the existing tools and efforts for new initiatives towards the diversification of energy supply will improve Europe's energy security and the security of the Alliance as a whole. NATO's role here is to add value to EU energy security policy and to pave the way towards energy security.

18 Opening speech by H.E. Mr. Daniel Cristian Ciobanu, Ambassador of Romania to Azerbaijan, International workshop ensuring energy security in the Caspian basin and NATO's role in protecting critical energy infrastructure, Baku, November 22, 2012.

19 Aurora Ganz, "Energy Security Issues: Is NATO Becoming a (Pivotal) Actor?" SciencesPo, Centre de Recherches Internationales, September 2014, accessed June 4, 2017, http://www.sciencespo.fr/ceri/fr/content/dossiersduceri/energy-security-issuesnato-becoming-pivotal-actor.

20 Bartlett and Samvelidze, "Turkey and the South Caucasus."

21 Aynur Karimova, "Kerry appraises Azerbaijan's role in international security system," AZERNEWS, March 31, 2016, accessed January 18, 2018, http://www.azernews.az/ nation/94480.html. 
Considering the strategic nature of the region, NATO should keep a close eye on developments in the South Caucasus, both politically and economically. In addition, Russia has shown that it uses the frozen conflicts and energy as tools in order to push NATO away from its borders and to weaken its cohesion. If we consider all non-NATO countries on the European periphery of Russia we would see that only Finland, Sweden and Belarus do not have any conflicts in their territories. The first two are neutral countries and the latter is a CSTO member. What we can deduce from this is that NATO membership for aspiring countries has become illusory, even wishful thinking for the foreseeable future. However, it does not mean that NATO should stay on the sidelines on the issue of the conflicts, because their continued existence is an important concern for overall European security. ${ }^{22}$

\section{Conclusion}

Russia will pull out all the stops in order to exert its influence in its "near abroad" and reassert itself as a dominant power as it has in the post-soviet space. The South Caucasus, with its proximity to Russia, occupies the first place in this "near abroad." The only way for South Caucasus countries (Georgia and Azerbaijan) to eradicate their problems regarding frozen conflicts is to strike the right balance between NATO and Russia, because the latter does not seem to want to give up its political ambitions in the region. But cooperation with NATO has the utmost importance for all three countries. That is why, since Armenia is a CSTO country, Georgia and Azerbaijan should follow the examples of Sweden and Finland to enhance further cooperation with NATO. The Alliance could increase Azerbaijani-Georgian military cooperation to encourage peace and stability in the South Caucasus through active partnership relations without actual membership of NATO. This is because every move that any South Caucasus country makes towards NATO membership might prompt a negative reaction from Russia. Subsequently, as it did during the Russo-Georgian war in 2008, NATO will be reluctant to respond to any Russian action. Thus, close practical, rather than political, cooperation with NATO will improve both Azerbaijan's and Georgia's defense capabilities in a similar way to Sweden and Finland. This kind of strategy could reduce any on-going tension between Russia and the West and may partially balance Russia's military presence in Armenia and in Georgia's breakaway regions.

Europe is vulnerable to energy coercion and the Azerbaijan-Georgia-Turkey tandem offers it the best option to withstand this coercion. Maintaining security in the region is in the interest of energy-importing, transit and energy-exporting countries, which need to ensure the security of their industry and pipeline infrastructure. That is why the South Caucasus region has to be considered as a buffer zone between NATO and Russia until the "frozen conflicts" are settled and all

22 Xavier Follebouckt, "The South Caucasus's Still Frozen Conflicts," Atlantic Voices 6, no. 7 (July 2016), http://atahq.org/2016/07/atlantic-voices-south-caucasus/. 
energy projects are implemented. But choosing only one side can only exacerbate the existing crises for Georgia and Azerbaijan in their territories.

\section{About the Authors}

Prof. Elman Nasirov is Doctor in political sciences and Director of the Institute of Political Studies of the Academy of Public Administration under the President of Azerbaijan. He serves also as member of parliament of the Republic of Azerbaijan.

Khayal Iskandarov is Chief of the editorial section of the War College of the Armed Forces, Republic of Azerbaijan. He holds a Master degree in military sciences and is currently pursuing a PhD degree in military sciences and national security. E-mail: xayal1333@gmail.com.

Sadi Sadiyev, PhD in philology, is Associate professor in the War College of the Armed Forces, Republic of Azerbaijan. E-mail: sanansadiyev@yahoo.co.uk. 